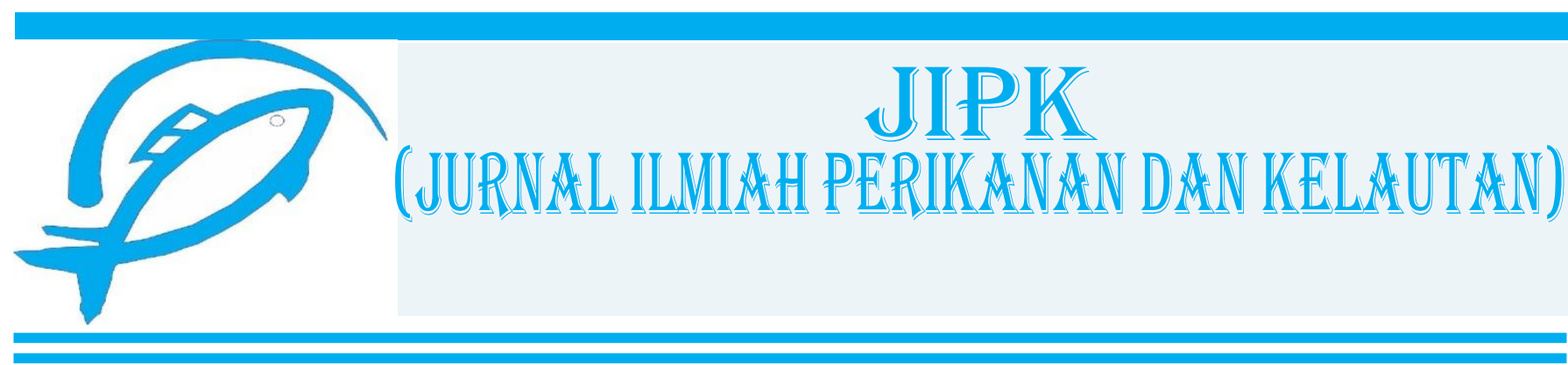

Research Article

\title{
Analysis Model of Giant Prawns Population (Macrobrachium rosenbergii) in Estuary Edge of Sembakung Waters, Nunukan, Indonesia
}

\author{
Agus Indarjo', Gazali Salim²* (D), Christine Dyta Nugraeni ${ }^{3}$, Lukman Yudho Prakoso ${ }^{4}$, Permana Ari \\ Soejarwo ${ }^{5}$, Rukisah ${ }^{6}$, Yen Thi Hong Pham ${ }^{7}$, Achmad Daengs G. S ${ }^{8}$, Hariyadi², Abdul Jabarsyah² \\ ${ }^{1}$ Department of Marine Science, Faculty of Fisheries and Marine Science, Diponegoro University, Jl. Prof. H. Soedarto, S.H. \\ Tembalang Semarang, 50275 Indonesia \\ ${ }^{2}$ Department of Waters Resources Management, Faculty of Fisheries and Marine Science, University of Borneo Tarakan, Kota \\ Tarakan, Kalimantan Utara, Indonesia \\ ${ }^{3}$ Department of Fisheries Product Technology, University of Borneo Tarakan, Kota Tarakan, Kalimantan Utara, Indonesia \\ ${ }^{4}$ Universitas Pertahanan Indonesia. Kawasan IPSC, Sentul, Sukahati, Kec. Citeureup, Bogor, Jawa Barat 16810, Indonesia \\ ${ }^{5}$ Indonesian Center for Social and Economic Research, Ministry of Maritime Affairs and Fisheries, Jakarta Pusat 10110 Indonesia \\ ${ }^{6}$ Fisheries Aquaculture, Faculty of Fisheries and Marine Science, University of Borneo Tarakan. Indonesia. \\ ${ }^{7}$ Department of International Business, National Kaohsiung University of Science and Technology, Kaohsiung, Taiwan. No.415, \\ Jiangong Rd., Sanmin Dist., Kaohsiung City 807, Taiwan. China \\ ${ }^{8}$ Department of Management, Faculty of Economics, University 45, Surabaya. Indonesia
}

\section{OPEN ACCESS}

\section{ARTICLE INFO}

Received: April 27, 2020

Accepted: September 26, 2020

Published: September 27, 2020

*) Corresponding author:

E-mail:axza_oke@yahoo.com

Keywords:

Allometric

Mortality

Exploitation

Growth

M. rosenbergii

This is an open access article under the CC BY-NC-ND license (http://creativecommons.org/licenses/by-nc-nd/4.0/)

\section{Abstract}

Giant prawns (Macrobrachium rosenbergii) is a crustacean class that has the largest size and its habitat in Sembakung waters included brackish water (estuarine) with a salinity variable of 6.5+0.5 ppt and a temperature variable of $28.5 \pm 0.5^{\circ} \mathrm{C}$ and a variable $\mathrm{pH}$ of 6 (acidic). The objective of this research was to analyze the growth and mortality model of giant prawns ( $M$. rosenbergii) that was taken from the catch of fisherman in the estuary, Sembakung sub district, Nunukan Regency, Indonesia. The study was conducted for 3 months from November 2019 to January 2020. The sampling was by using a survey method with purposive judgment sampling based on a catch of 14 fishermen who used the bottom fish pot from Sembakung waters, Nunukan Regency (Indonesia). The data collection included data of sex, total length, and the total weight of giant prawns. While analysis was employed for growth pattern, condition index, Von Bertalanffy growth, and mortality. The results obtain the sex ratio of male and female giant prawns 1:3.67. The growth pattern of male and female giant prawns were allometric negative. The growth of the von Bertalanffy model for infinitive growth of male giant prawns were $21.219 \mathrm{~cm}$ and female were $18.42 \mathrm{~cm}$, respectively the mortality from giant prawns obtain total male mortality is 2,257 , catch mortality is 1.92 and natural mortality is $33.75 \%$ with an exploitation rate of 0.85 (85\%). The total female mortality is 1.528 , catch mortality is $120.1 \%$ and natural mortality is $32.69 \%$ with an exploitation rate of 0.786 (78.6\%).

Cite this as: Indarjo, Salim, G., Nugraeni, C. D., Prakoso, L. Y., Soejarwo, P. A., Rukisah, Pham, Y. T. H., Daengs, A. G. S., Hariyadi, \& Jabarsyah, A. (2020). Analysis Model of Giant Prawns Population (Macrobrachium rosenbergii) in Estuary Edge of Sembakung Waters, Nunukan, Indonesia. Jurnal Ilmiah Perikanan dan Kelautan, 12(2):236-249. http://doi.org/10.20473/jipk. v12i2.18829 


\section{Introduction}

Indonesia is one of the Mega biodiversity in the world due to it has a strategic location where the territory was located in the equatorial region that has a warm climate so it can be used as one of the ecological preferences for marine biota Nikijuluw, (2002); Davassi (2011) ; Kementerian PPN/Bappenas (2014); Paul et al. (2016) ; Muchlisin et al. (2017); Putra et al. (2018), one of them is Sembakung waters in Nunukan Regency. Badan Pusat Statistik (2013) explained that Nunukan is one of the districts that have high potential of marine and brackish water resources in the Kalimantan Province which consists of 15 districts (in 2012) and one of them is in Sembakung. Based on data of Badan Pusat Statistik (2014) explained that Sembakung has potential resources of Giant prawns that were lived in the estuary edge of Sembakung waters. Giant prawns in Indonesia according to Ali (2009); de Man (1879); Munasinghe and Thushari (2010); Khalis et al. (2016), known as Macrobrachium rosenbergii species. Giant prawns (M. rosenbergii) can live in the range of high salinity, fresh waters like rivers and swamps as well as brackish waters (estuary) even up to 20 ppt salinity. The research of Habashy and Hassan (2011); Ipandri (2017); Waluyo et al. (2019) stated that giant prawns larvae can live up to $15 \mathrm{ppt}$ salinity (brackish) even according to (New, 2002) explaining that giant prawns has ecological preferable with euryhaline spread to $20 \mathrm{ppt}$ (seawater). The spawning season of $M$. rosenbergii in Vembanad Lake extends from August to December with a peak in September-November and after completing the larval life in brackish water juveniles ascend upstream parts of rivers adjacent to the lake by December onwards (Raman, 1967; Kurup et al., 1992). Juveniles and large males of $M$. rosenbergii are fully at home in the river mouths adjacent to the brackish water areas where salinity was nearly 18 ppt (Raman, 1964).

One of the best fishing products is shrimp. Indonesia ranks fourth after India, Ecuador, and Vietnam as the world's largest frozen shrimp exporter in 2018 (Widowati, 2019). In 2019, there was a decrease in the selling price of shrimp in the global market. Previously, the average price of shrimp in the United States was US \$ 9.79 per kilogram, to US \$ 8.88 per kilogram in the I-2019 quarter (Lidyana, 2019). Giant prawns is one of the economic income for the local society because it was the main catch that has an economic value in terms of prices that are quite high with a price range of Rp. 40.000 to Rp. $75.000 / \mathrm{kg}$. According to Batubara and Gustianty (2016) explained the price of Galah shrimp ( $M$. rosenbergii de Man) is a high economic level fishery commodities with a selling priece of up to Rp. $185.000 / \mathrm{kg}$.
According to Mahendra and Rizal (2019) added that The high selling price has an impact on the high demand for shrimp poles. According to Gunaratne et al. (2019) explains that Giant Shrimp (M. rosenbergii) is very nutritious and popular seafood for local consumers, especially in the North Central Province of Sri Lanka.

The great economic opportunity causes an increase in the number of fishermen and the number of fishing gear used in catching giant prawns. The giant prawn fishing gear is not environmentally friendly. En vironmentally friendly fishing gear means that it does not damage the ecosystem and does not damage the biota (degradation of size, shape, and population). The fishing gear was the bottom fish pots which has an environmentally friendly trait. However, if the bottom fish pots made in large numbers, it will cause damage to biota (degradation of size, body shape, and population) giant prawns ( $M$. rosenbergii) in Sembakung waters.

Besides, the economic opportunities can lead to exploit of aquatic resources for giant prawns in Sembakung brackish waters that were able to cause biota damage, such as the degradation of size and body shape of giant prawns then causes a large rate of exploitation magnitude of catch. Estimation in terms of exploitation of giant prawns to analyze the occurrence of overfishing, so it was necessary to conduct the study about the exploitation rate based on the catch of fishermen. So it needs research on population with growth model approach, mortality, and exploitation rate models. The research is needed regarding the size and weight of giant prawns to get a correlation to the growth of the von Bertalanffy model, the mortality and exploitation rate. According to Firdaus et al. (2020), Indarjo et al. (2020a), Salim (2013), Salim (2015), explained the models and patterns of biota growth in the waters can be used as information reference to describe the growth of biota that was lived in waters.

Research about allometric growth and condition index (Firdaus et al., 2018) has been carried out by Sofian and Sari (2018) with the title study on growth patterns of giant prawns in the Ogan River, South Sumatera obtained growth results in estuary edge was negative. However, the research on population models of giant prawns in the brackish water of Sembakung, Nunukan Regency is rarely conducted.

The research objective was to analyze the growth and mortality models of giant prawns ( $M$. rosenbergii) from the catches of fishermen in the estuary edge area of Sembakung sub-district, Nunukan Regency, Indonesia. 


\section{Materials and Methods}

The research was conducted for three months from November 2019 to January 2020. The determination of the study area was done by using a purposive judgment sampling method where it was the habitat of giant prawns which is following ecological preferences due to fishermen catch giant prawns using bottom fish pots.

\subsection{Materials}

\subsubsection{Research Parameters}

The research parameters for giant prawn samples were growth and mortality parameters. Growth parameters included sex ratio, allometric growth, condition index, age structure, and growth of von Bertalanffy variables. The mortality parameters were total mortal- ity, catch mortality, natural mortality and exploitation rate variables.

\subsection{Method}

The research used quantitative descriptive methods with a case study approach. Sampling was taken with a survey using purposive judgment sampling and data collection using laboratory-scale methods, where the data instead of sex, total length, and the total weight of giant prawns.

\subsection{Analysis Data}

\subsubsection{Variable of sex ratio}

Variables from the sex ratio of giant prawns were carried out by laboratory scale method with observation based on gender identification guidelines. The variable of sex ratio was done by comparing the number of male and female giant prawns using the Chi-square test (Steel and Torrie, 1993).

$$
X^{2}=\sum \frac{(\text { Oi-ei })^{2}}{\text { ei }}
$$

Note: $\mathrm{Oi}=$ frequency of giant prawns male and female observed

ei $=$ the expectation frequency, where the frequency of giant prawns plus females divided by two

$\mathrm{X}^{2}=\mathrm{a}$ value for the random of variable $\mathrm{X}^{2}$ approaching the distribution of $\mathrm{X}^{2}$

\subsubsection{Variable of Allometric growth}

The allometric growth model was the length and weight value to analyze population growth overall used the equation based on (Bal and Rao, 1984) and the estimation refers to Effendie (1979):

$$
\mathbf{Y}=\mathbf{a}+\mathbf{X}^{\mathbf{b}} \quad \text { or } \quad \log Y=\log \mathbf{a}+\mathbf{b L o g} X
$$

Note: $\mathrm{Y}=$ Total weight of $M$. rosenbergii (gram)

$\mathrm{X}=$ Total lenght $M$. rosenbergii $(\mathrm{mm})$

$\mathrm{a}+\mathrm{b}=$ coefficient (intercept)

The value of $b$ was an allometric coefficient that reflected relative growth. When $\mathrm{b}$ value $=3$, allometric growth characteristic was isometric, length growth was the same with weight growth. $\mathrm{b}$ value $<3$ (allometric negative) or $\mathrm{b}>3$ (allometric positive), so length growth was not the same with weight growth. The correlation between length and weight calculated by correlation coefficient Effendie (1979).

\subsubsection{Variable Condition index}

Condition index of the fish was based on five criteria i.e. very flatfish (0.01-0.50), flatfish boy (0.510.99 ), proportional/ideal fish (1), fat fish (1.01-1.50), and the obese fish $(>1.50)$ (Firdaus and Salim, 2011; Salim, 2013; Salim, 2015; Firdaus et al., 2018; Indarjo et al., 2020a; Firdaus et al., 2020 ; Indarjo et al., 2020b ; Indarjo et al., 2020c).

The allometric growth used Weatherley (1972) and isometric growth used Lagler (1949) and Effendie (1979) method. Based on (Lagler, 1949) in (Effendie, 1979) to obtain fish condition factor with isometric growth characteristic can use this equation as follows:

$$
K_{(\mathrm{TI})}=10^{5} \times \frac{w}{L^{3}}
$$

$\mathrm{W}$ = total weight of $M$. rosenbergii (g);

$\mathrm{L} \quad=$ total length of $M$. rosenbergii $(\mathrm{mm})$;

$10^{5}=$ the equation was taken, so $\mathrm{K}_{(\mathrm{TI})}$ value is close to 1 .

The fish/crustacea condition factor with fish/ crustacea allometric characteristic used this equation (Weatherley, 1972):

$$
K n=\frac{\hat{W}}{W}
$$

$\mathrm{W}=$ total weight of of $M$. rosenbergii (g);

$\hat{\mathrm{W}}=$ allegation of total weight of $\mathrm{M}$. rosenbergii (g); $\mathrm{W}=\mathrm{a} \mathrm{L}{ }^{\mathrm{b}}$ obtained using the regression equation of length-weight) correlation. 


\subsubsection{Variable of Age Structure}

Variable of age structure used modus class shift method that has correlation with Von Bertalanffy based on (Sparre and Venema, 1999a) as follows:

$$
\begin{gathered}
(\Delta \mathbf{L} / \Delta t)=\left(\mathbf{L}_{2}-\mathbf{L}_{1}\right) /\left(\mathbf{t}_{2}-\mathbf{t}_{1}\right) \\
\mathbf{L}_{(\mathbf{t})}=\left(\mathbf{L}_{2}+\mathbf{L}_{1}\right)
\end{gathered}
$$

Note : $\Delta \mathrm{L} / \Delta \mathrm{t}=$ Relative growth; $\Delta \mathrm{L}=$ Length of the $M$. rosenbergii; $\Delta \mathrm{t}=$ Difference of sampling time; $\mathrm{L}_{(\mathrm{t})}=$ Modus of average length

The equation of the linear curve was obtained by plot between $\mathrm{L}_{(\mathrm{t})}$ and $(\Delta \mathrm{L} / \Delta \mathrm{t})$ value to obtain the following linear line equation:

$$
\mathbf{Y}=\mathbf{a}+\mathbf{b} \mathbf{x}
$$

Note $: \mathrm{a}=\left(\left(\sum \mathrm{y} / \mathrm{n}\right)-\left(\mathrm{b}\left(\sum \mathrm{x} / \mathrm{n}\right)\right)\right)$;

$$
\mathrm{b}=\left(\mathrm{n} \sum(\mathrm{xy})-\left(\sum \mathrm{x}\right)\left(\sum \mathrm{y}\right)\right) /\left(\mathrm{n} \sum \mathrm{x}^{2}-\left(\sum \mathrm{x}\right)^{2}\right)
$$

The average value of modus length obtained from the regression equation is used to calculate the asymptotic length $(L \infty)=-a / b$, then the growth coefficient is -b. Age theoretical of $M$. rosenbergii when the length is zero can be expected separately by empirical equation (Pauly, 1984) in (Sparre and Venema, 1998) and (Sparre and Venema, 1999b):

$\log \left(-t_{0}\right)=0,3922-0,275(\log L \infty 1,038(\log K)$

Note: $\mathrm{L} \infty=$ asymptotic length of $M$. rosenbergii (cm); $\mathrm{K}$ = growth rate coefficient of $M$. rosenbergii; $\mathrm{t}_{0}=$ Age theoretical of $M$. rosenbergii when the length is zero (year).

\subsubsection{Variable of Von Bertalanffy Model}

Equation model based on the growth curve and class range of $M$. rosenbergii by using the Von Bertalanffy (1938), (Sparre and Venema, 1998) with (Gulland and Holt, 1959) approach in (Sparre and Venema, 1999a) as follows:

$$
\mathbf{L t}=\mathbf{L} \infty\left(1-\mathbf{e}^{-\mathbf{k}(t-10)}\right)
$$

Note : $\mathrm{Lt}=$ Length of M.rosenbergii with age $\mathrm{t}$ (unit of time) ; $\infty_{\infty}=$ Maximum length of $M$. rosenbergii theoretically (asymptotic length) ; $\mathrm{K}=$ Coefficient growth of $M$. rosenbergii (per unit of time); $\mathrm{t}_{0}=$ Theoretical age of $M$. rosenbergii when the length is zero.

\subsubsection{Parameter Mortality}

Natural mortality (M) was estimated using Pauly's empirical formula (Pauly, 1984), where:

\section{$\log M=0,00660,279 \log L \infty+0,6543 \log K+$ $0,4634 \log \mathrm{T}$}

Total mortality (Z) was estimated using the Beverton and Holt formula (Sparre and Venema, 1998); (Sparre and Venema, 1999b) as follows:

$$
\mathrm{Z}=\mathrm{K} \cdot\left[\frac{\mathrm{L}_{\infty}-\bar{L}}{\bar{L}-L^{\prime}}\right]
$$

Mortality Capture (F) as follows:

$$
\mathbf{F}=\mathbf{Z}-\mathbf{M}
$$

The exploitation rate (E) used the formulation of Baranov (Sparre and Venema, 1999a; Sparre and Venema, 1998) as follows:

$$
\mathrm{E}=\frac{F}{F+M}=\frac{F}{Z}
$$

Note : $\mathrm{E}=$ Rate of exploitation; $\mathrm{Z}=$ Total mortality $; \mathrm{F}=$ Capture mortality ; $\mathrm{M}=$ Natural mortality

\section{Results and Discussions}

\subsection{Sex Ratio and Size Distribution}

The research conducted in Sembakung waters of Nunukan Regency (Indonesia) is one of the habitat areas of giant prawns. The giant prawns are estuarian edge shrimp that had a range of salinity to adapt in Estuary waters, where based on the research results obtained salinity variable range of $6.5 \pm 0.5 \mathrm{ppt}$ with an average of $6.4 \mathrm{ppt}$; variable temperature ranges from $28.5 \pm 0.5^{\circ} \mathrm{C}$ with an average of $28.6^{\circ} \mathrm{C}$ and variable $\mathrm{pH}$ 6 (acidic). Based on the results of research to 14 bottom fish pots, there were 210 shrimps was caught with gender identification for giant prawns 45 males (21.4\%), 165 female (78.6\%) and the sex ratio of male and female of giant prawns was 1: 3.67. According to New and Kutty (2010) explain that females have higher proportion than males in prawn populations. For male, the size was $15.1 \pm 4.2 \mathrm{~cm}$ with a range of body weight was $40.36 \pm 29.5$ grams and female with a size of $13.85 \pm 3.95 \mathrm{~cm}$ with a range of body weight as $31.12 \pm 20.12$ grams.

Figure 1 described the smallest size of giant prawns was $10.2 \pm 03 \mathrm{~cm}$ and the largest size was 18.7 $\pm 0.6 \mathrm{~cm}$ as much as $1.4 \%$ from a population estimated of giant prawns representing in Sembakung waters, Nunukan Regency (Indonesia). 


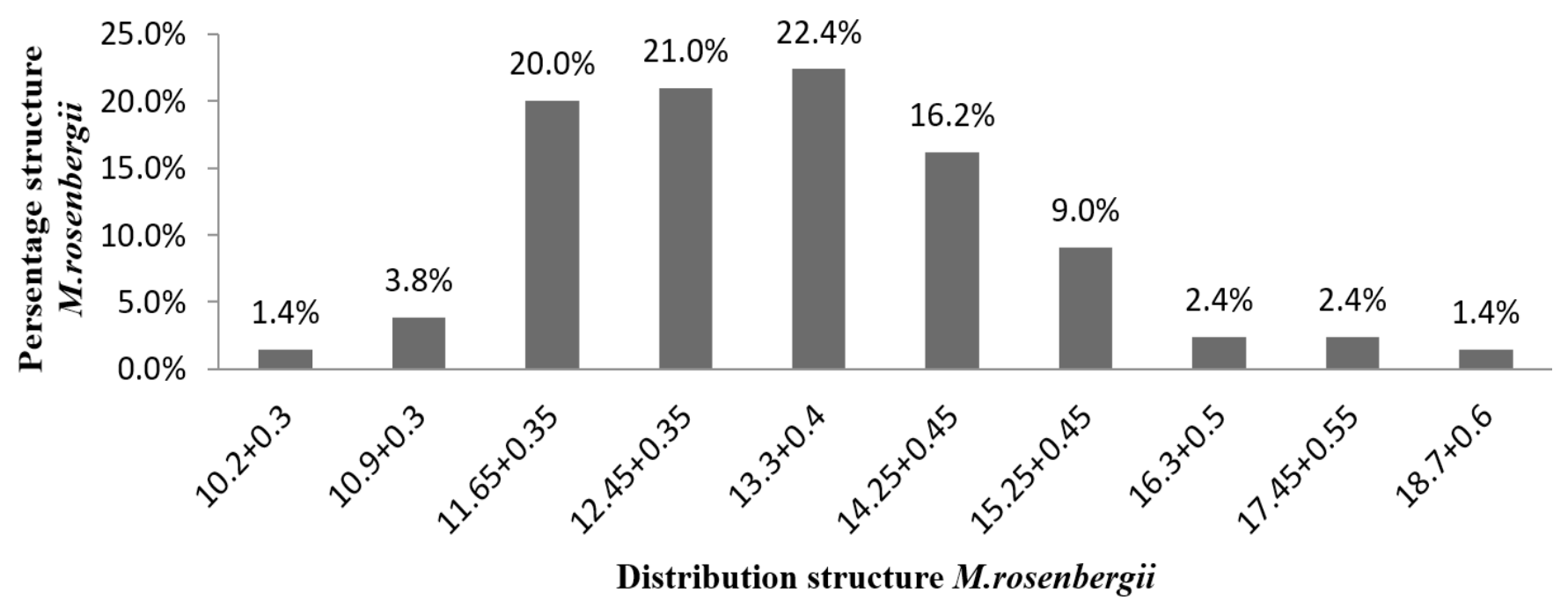

Figure 1. Percentage of Macrobrachium rosenbergii distribution structure

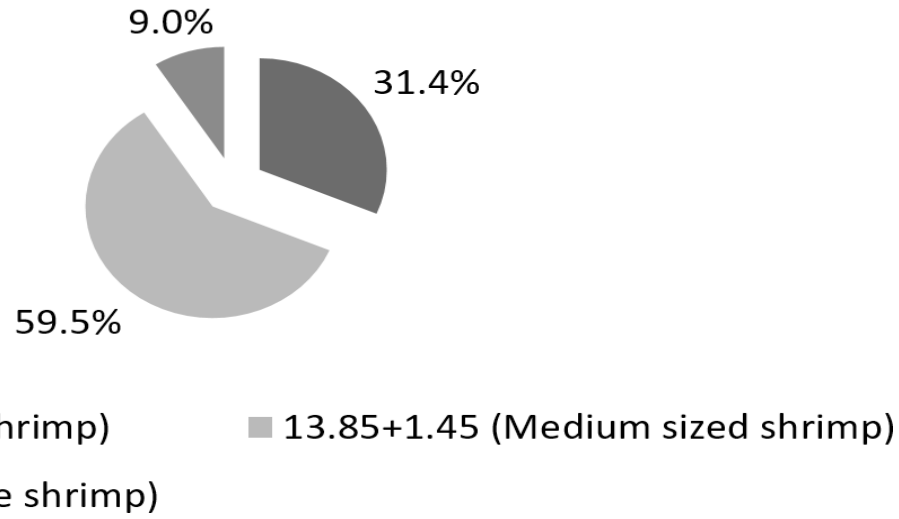

Figure 2. Criteria class of giant prawns based on total length M.rosenbergii

\subsection{Allometric Growth Variable}

The research of giant prawns growth was allometric with the smallest size was $10.9 \mathrm{~cm}$ with a weight of 10.86 grams and the largest size was $19.3 \mathrm{~cm}$ with a weight of 69.85 grams. The standard deviation of total length and the total weight of giant prawns was $15.1 \pm 4.2 \mathrm{~cm}$ and $40.335 \pm 29.495$ grams. The allometric growth explains comprehensively the population of giant prawns in nature so it describes the conditions of giant prawns growth in Sembakung waters. The growth of giant prawns based on linear regression equation $\mathrm{y}$

$=2.644 \mathrm{x}-1.6419$ with a correlation value of 0.8275 (82.75\%), has negative allometric properties because the growth of giant prawns was seen from the $b$ value.

The research of allometric growth showed the smallest size of female giant prawns was $9.9 \mathrm{~cm}$ with a weight of 11 grams and the largest size was $17.8 \mathrm{~cm}$ with a weight of 51.23 grams. The standard deviation of total length and the total weight of giant prawns was $13.85 \pm 3.95 \mathrm{~cm}$ and 31,115 \pm 20.115 grams. Based on the regression equation in Figure 4, $y=2.3484 \mathrm{x}$ 1.2878 with a correlation value of 0.8225 (82.55\%).

The sampling of giant prawns in Sembakung waters was conducted by using a purposive judgment sampling method where it based on the catches of fishermen using bottom fish pots. The giant prawns that were obtained were taken from the catch of 14 fishermen (Figure 4) and the results data processing using the allometric growth model comprehensively showed in Figure 5.

The allometric growth model of fishermen's catches as many as 14 times for sampling were 12 times the growth characteristics of giant prawns was negative allometric $(b<3)$ with a percentage of $85.7 \%$ and for two times was positive allometric $(b>3)$ with a per percentage of $14.3 \%$. This was consistent with the results of the study in Figure 3 and Figure 4 regarding 
the correlation of total length and the total weight of male prawns $(b=2,644)$ and female $(b=2.3484)$, for each having negative allometric $(\mathrm{b}<3)$. It explains that the average growth of giant prawns as much as $85.7 \%$ was negative allometric. There was high food competition so the giant prawns get rapid molting process to growth. In molting process requires enough energy, if the lack of it would cause natural mortality. Based on Figure 13. showed that the natural mortality of giant prawns was quite high at $33.7 \%$ for males and females was $32.7 \%$.
According to Raswin et al. (1981), the difference of the growth patterns from fishermen's catches in Sembakung waters was suspected due to water conditions, one of them was salinity of giant prawn habitat, the presence of food abundance, and differences of shrimp size that will be analyzed. Murni (2004) stated that the ability to utilize feed, food availability, space, water temperature, and adaptation to certain salinity were the factors that influence growth.

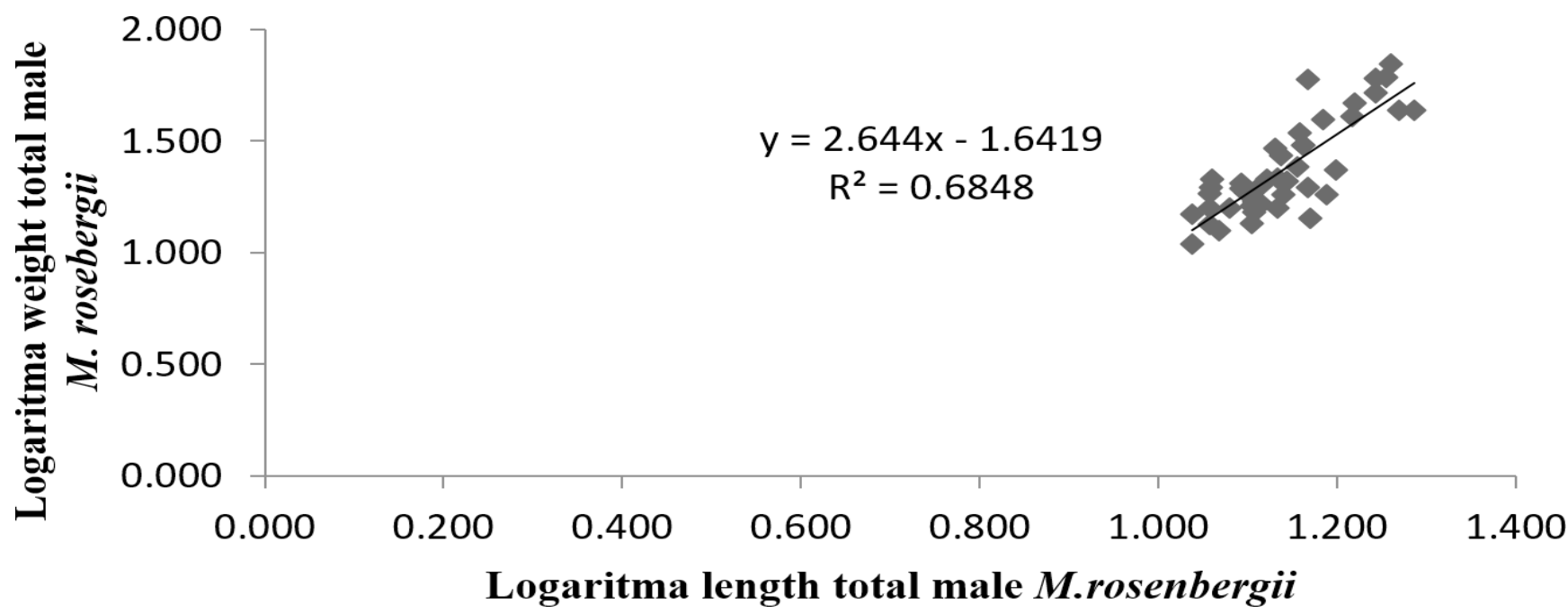

Figure 3. The correlation of total length and the total weight of male giant prawns

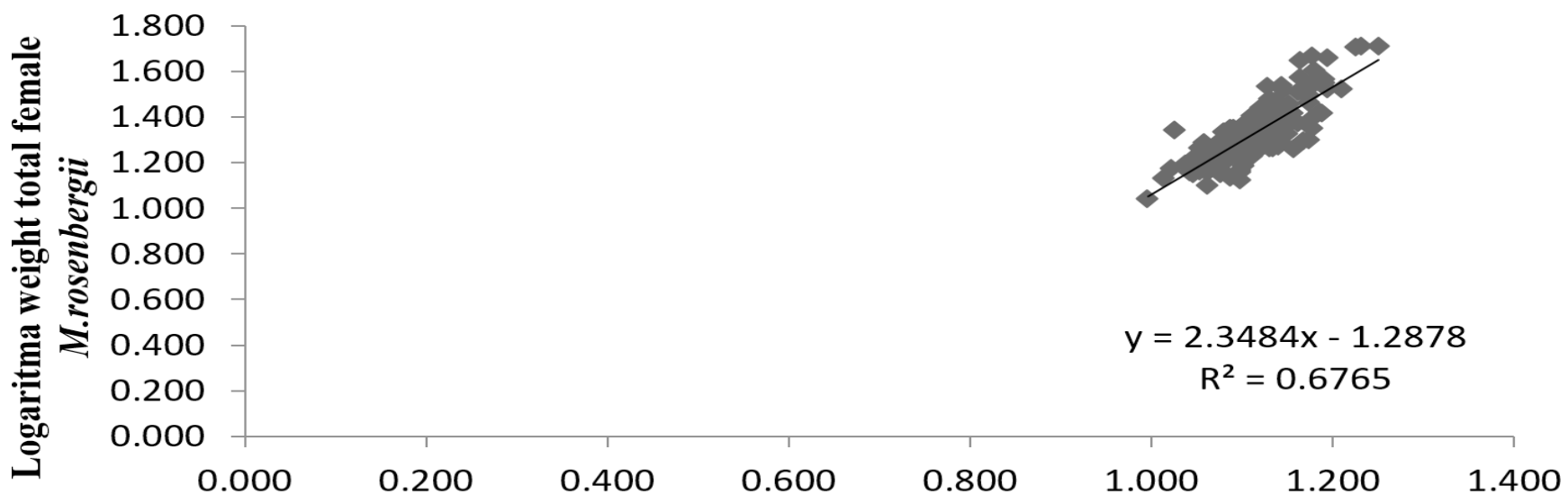

Logaritma length total female M.rosenbergii

Figure 4. The correlation of total length and total weight of female giant prawns 


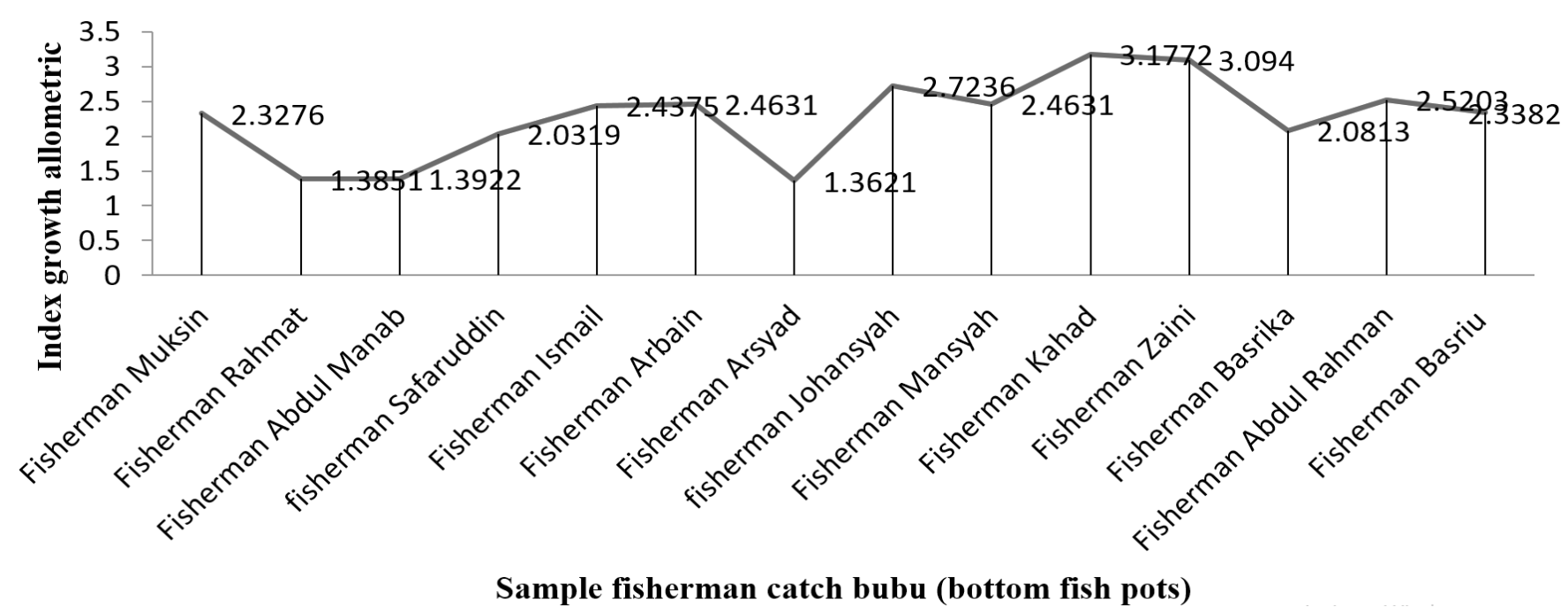

Figure 5. The average index of allometric growth based on sample fisherman

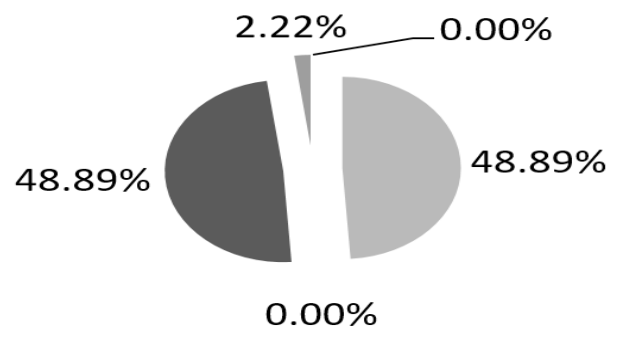

Very thin body shape of male (0.01-0.49) $\square$ Thin body shape of male (0.50-0.99)

- Ideal body shape of male (1)

- Fat body shape of male (1.01-1.50)

Very fat body shape of male (>1.50)

Figure 6. Percentage condition index of male giant prawns distribution structure

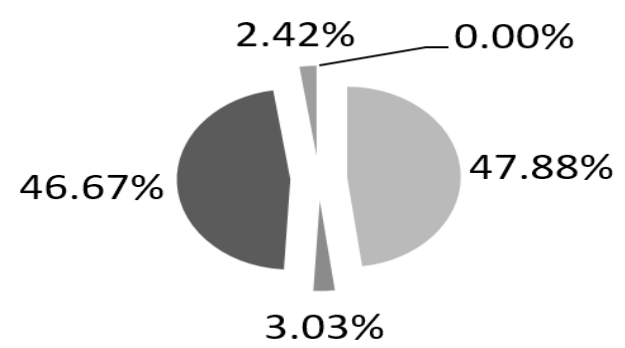

$\square$ Very thin body shape of female (0.01-0.49) $\square$ Thin body shape of female (0.50-0.99)

- Ideal body shape of female (1)

Fat body shape of female (1.01-1.50)

Very fat body shape of female (>1.50)

Figure 7. Percentage condition index of female giant prawns distribution structure 


\subsection{Condition Index Variable}

Condition index according to Indarjo et al. (2020a), Indarjo et al, (2020b), Indarjo et al, (2020c); Salim (2013), Salim (2015) explained the body shape of giant prawns where it was categorized into 5 parts. According to Salim (2013) stated the index criteria of body shape for Pisces / crustaceans were the very thin body, thin body, ideal/proportional body, fat body, and very fat body shape. Body shape (condition factor) according to Salim (2013) described the body shape of the Pisces / crustacean class, i.e. thin, fat and proportional.

According to Indarjo et al. (2020b), Salim (2013), Salim (2015) explained the use of condition index criteria based on allometric growth models obtained from the regression equation. The determination of the condition index model was based on two growth models, they were allometric and isometric growth. Condition index criteria used by Indarjo et al. (2020a), Salim (2013), Salim (2015) based on allometric growth according to Weatherley (1972). Condition index criteria according to Salim (2013) in Table 2 (Indarjo et al., 2020b ; Salim, 2015), were very thin body shape with a condition index range from $0.01-0.50$; thin body shape $0.51-0.99$; body shape proportional to the condition index was 1 ; fat body shape $1.01-1.50$ and very fat $>1.50$.
Based on Figure 8, it explains about the 14 giant prawn samples obtained from different fishermen in Sembakung waters, where there were three criteria was found about the condition index of Giant prawns comprehensively. The condition criteria index according to Indarjo et al. (2020a), Salim (2013), Salim (2015) obtained 4 criteria for the comprehensive growth of giant prawns, they were thin body shape and fat body shape had the same percentage of $48.57 \%$, ideal or proportional body shape of $2.86 \%$ and very fat body shape of $0.85 \%$.

Figure 8 explained that the body shape of giant prawns at the edge of the Sembakung waters for thin body shape has a high enough value to reach $48.57 \%$, where almost half of the giant prawns population was in nature.

\subsection{Age Structure Variable}

The age structure variable of giant prawns ( $M$. rosenbergii) was the size structure of total length that was used in data processing to obtain the age structure value (Indarjo et al., 2020a; Salim, 2013 ; Salim, 2015). Figure 9 explained the processing results of the age structure using two different variables based on the method of Sparre and Venema (1999a), they were the length and the rate of male $M$. rosenbergii growth.

Table 1. Correlation criteria

\begin{tabular}{lll}
\hline No & Correlation value & Correlation criteria \\
\hline 1 & 0 & : No correlation \\
2 & $>0-0,25$ & : Very weak correlation \\
3 & $>0,25-0,5$ & : Sufficient correlation \\
4 & $>0,5-0,75$ & : Strong correlation \\
5 & $>0,75-0,99$ & $:$ Very strong correlation \\
6 & 1 & : Perfect correlation \\
\hline
\end{tabular}

Noted: (Sarwono, 2006)

Table 2. Modification

\begin{tabular}{lll}
\hline No & Value range $\mathbf{K}^{\mathbf{T 1}}$ & Body shape \\
\hline 1 & $0,01-0,49$ & Very flat/lean \\
2 & $0,50-0,99$ & Flat/lean \\
3 & 1,00 & Proportional/ideal \\
4 & $1,01-1,50$ & Fat \\
5 & $>1,50$ & Very fat \\
\hline
\end{tabular}

Noted: (Effendie, 2002) 
In Figure 9 explains the regression equation between the length of male $M$. rosenbergii and the rate of male $M$. rosenbergii growth that the straight line on the $\mathrm{X}$-axis is the maximum length growth with an average growth rate based on the b value. In Figure 9, the maximum growth of male prawns is $21.219 \mathrm{~cm}$ with a growth rate of $0.091 \mathrm{~cm} /$ day. The correlation value between maximum length growth and growth velocity is $0.70431(70.431 \%)$. (Sarwono, 2006) in Table 1 explains that if the correlation value ranges between $0.5-0.75$, it had a strong correlation.
In Figure 10 explains two different variables of the age structure, they are the length and the rate female of $M$. rosenbergii growth. The regression equation on the linear line if it is located on the $\mathrm{X}$-axis, the growth of female giant prawns reaches the maximum length with a zero growth rate was $18.042 \mathrm{~cm}$ and the growth rate was $0.2744 \mathrm{~cm} /$ day. The correlation value of the regression equation was 0.56771 (56,771\%). According to Sarwono (2006) in Table 1, the correlation values between 0.5 - 0.75 had a strong relationship.

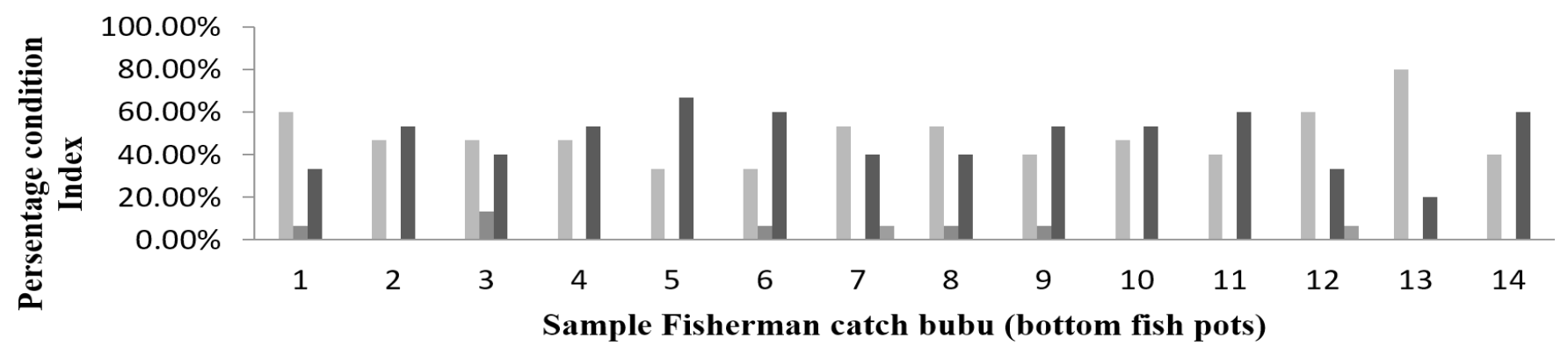

Very thin body shape $\square$ Thin body shape $\square$ Ideal body shape $\square$ Fat body shape $\square$ Very fat body shape

Figure 8. The average condition index percentage based on a sample of fisherman

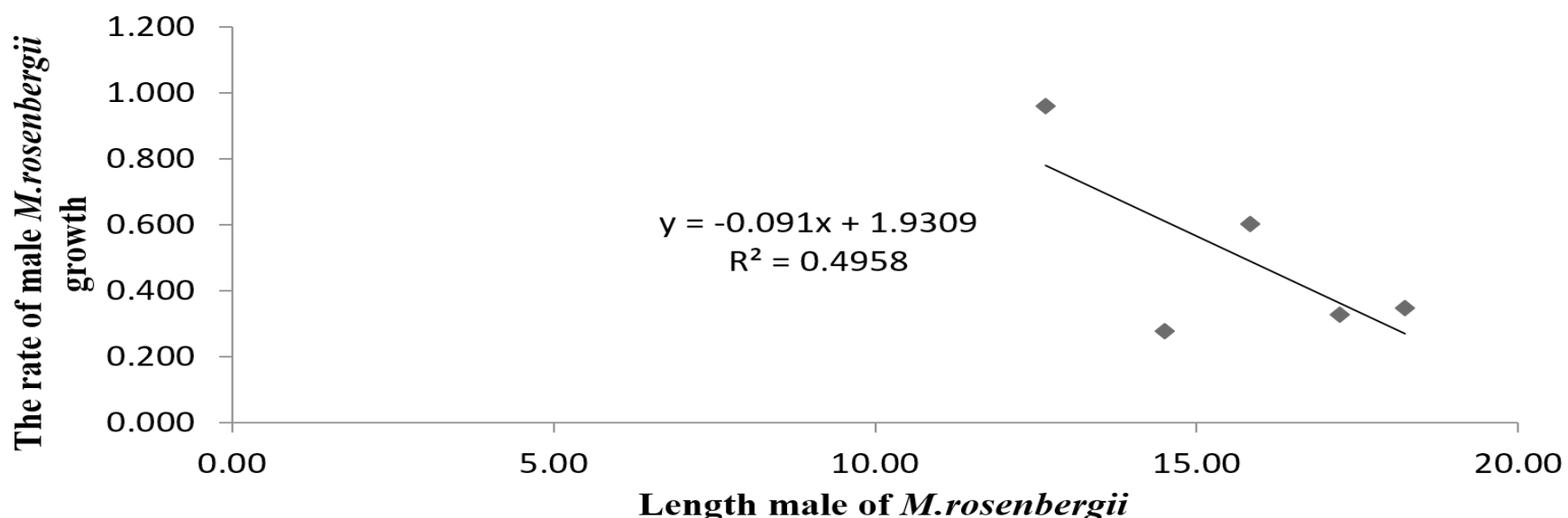

Figure 9. Von Bertalanffy growth model and length of male M. rosenbergii

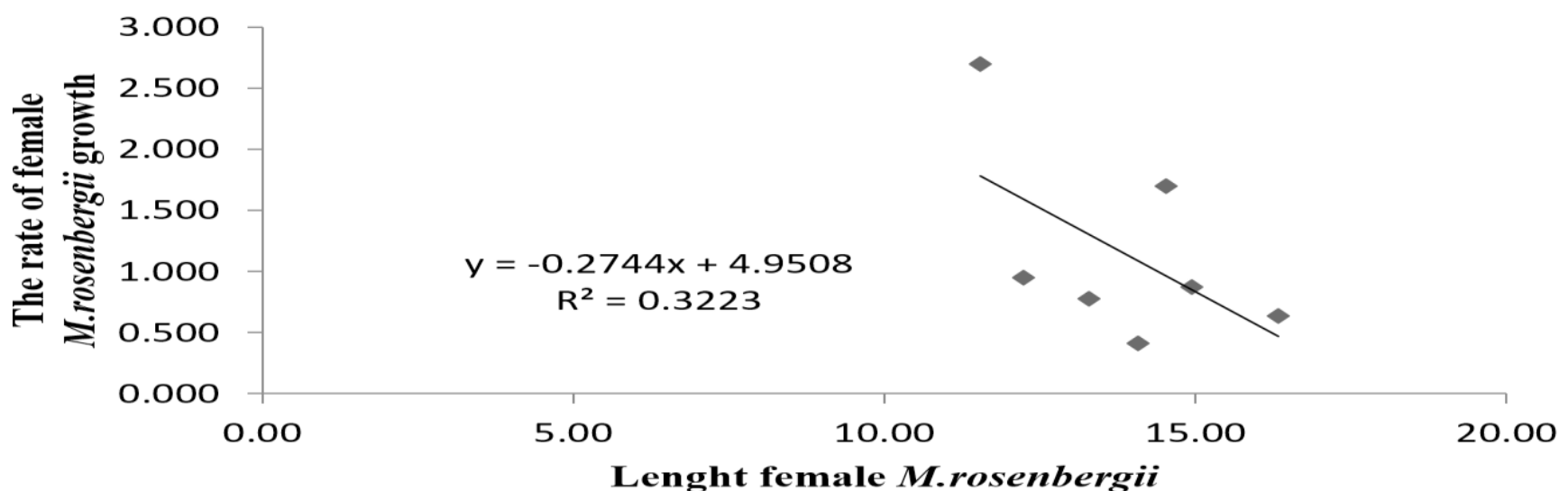

Figure 10. Von Bertalanffy growth model and length of female $\mathrm{M}$. rosenbergii 


\subsection{Von Bertalanffy growth}

Von Bertalanffy's growth explains the description of the total length of male giant prawns that can be determined based on age. It used the orthogonal type 6 polynomial equation where $\mathrm{y}=-1 \mathrm{E}-09 \mathrm{x} 6+4 \mathrm{E}-07 \mathrm{x} 5$ $5 \mathrm{E}-05 \mathrm{x} 4+0.0035 \mathrm{X} 3-0.1222 \mathrm{X} 2+2.2845 \mathrm{x}+2.605$ with a correlation value of 0.9999 (99.99\%). Sarwono (2006) explained that the range of correlation values between $0.75-0.99$ has a very strong relationship.
The growth of the von Bertalanffy model described in Figure 12 regarding the correlation between two different variables, they are the time/age variable and the total length of the female giant prawns (M. rosenbergii), so that it obtains the Von Bertalanffy model with the equation orthogonal polynomial type 6, it was $\mathrm{y}=-4 \mathrm{E}-09 \mathrm{X} 6+1 \mathrm{E}-06 \mathrm{X} 5+0.0049 \mathrm{X} 3-$ $0.1405 \mathrm{X} 2+2.2173 \mathrm{x}+2.3214$ with a correlation value of 0.999 (99.9\%). Sarwono (2006) stated that the correlation value between 0.75 - 0.99 has a very strong relationship.

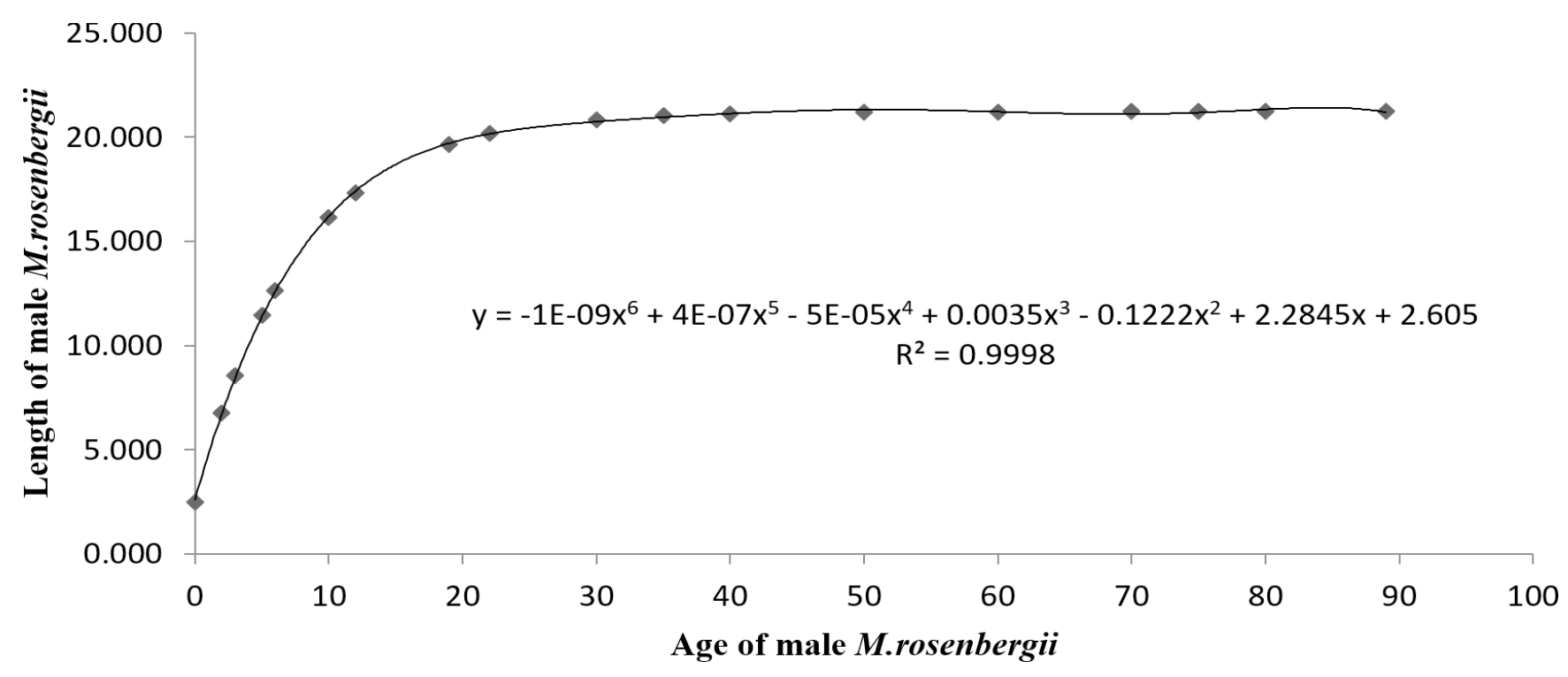

Figure 11. Von Bertalanffy polynomial orthogonal type 6 model of male M.rosenbergii

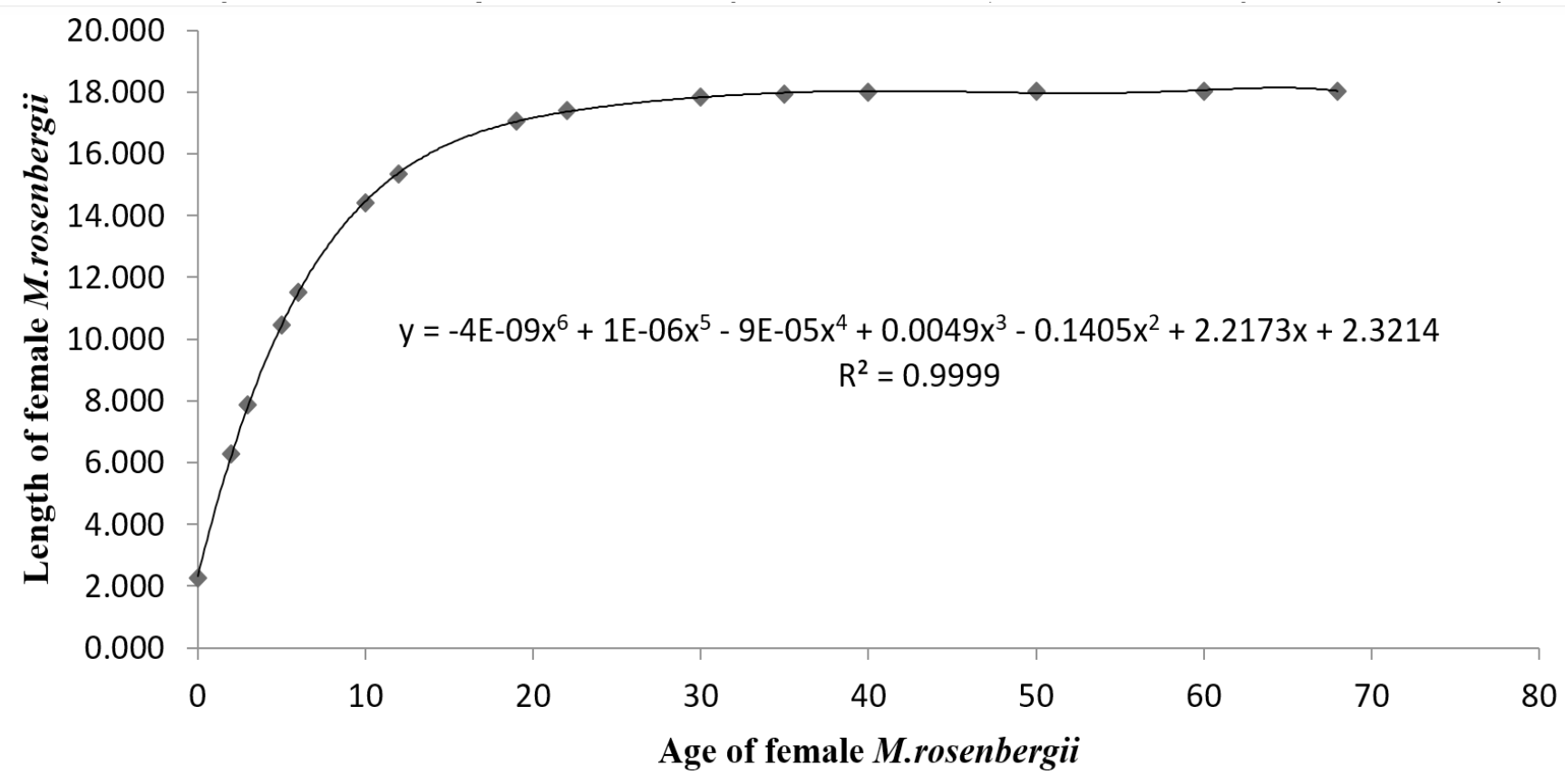

Figure 12. Von Bertalanffy polynomial orthogonal type 6 model of female M.rosenbergii 


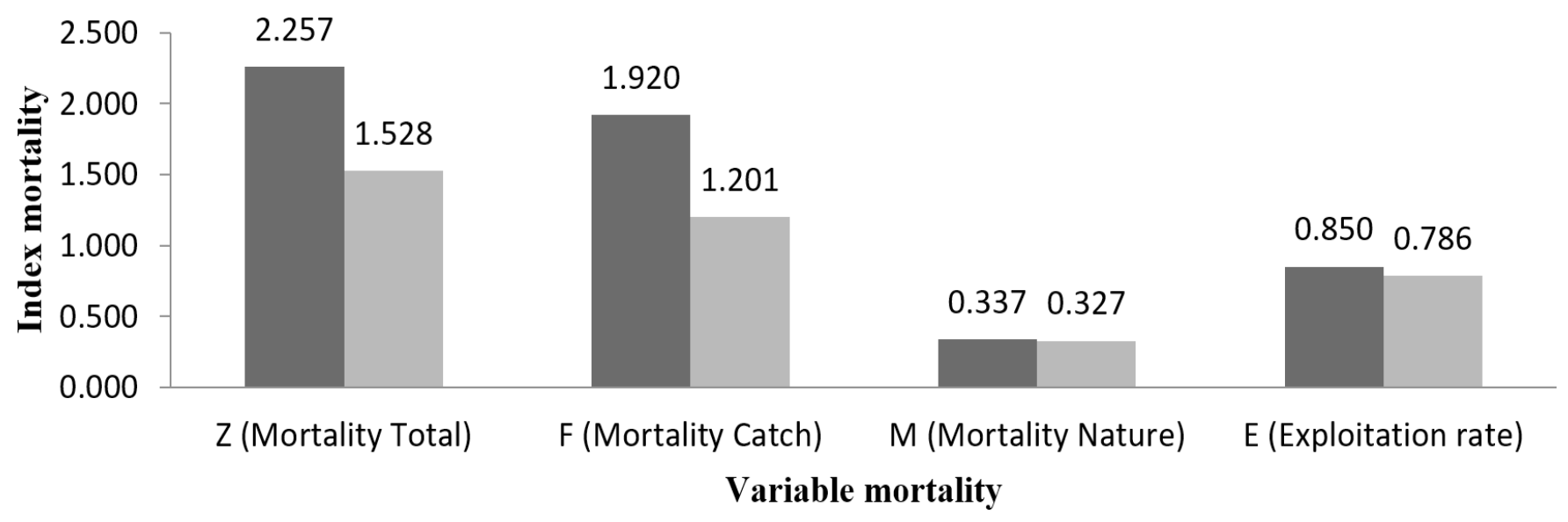

Figure 13. Variable mortality for male and female

\subsection{Variable of Mortality}

Figure 13 explains the mortality of giant prawns, both male and female, and the rate of exploitation. There were three types of mortality of giant prawns, they were total mortality, catch mortality and natural mortality. The exploitation rate of giant prawns is a part of the mortality parameter. Based on Figure 13 explains that the mortality of male giant prawns is higher than females. However, catch mortality shows significant value for male and female giant prawns were $1.920(1.920 \%)$ and 1.201 (120.1\%), respectively. This is supported by the value of the exploitation rate from male giant prawns as $85 \%$ has exceeded the value of overfishing which exceeds the threshold of $80 \%$. Meanwhile, the female giant prawns catch in the condition of overfishing has not yet and it reached $0.786(78.6 \%)$.

The results of a comprehensive study showed that the dominant sizes of shrimp found in range $13.3+0.4$ $\mathrm{cm}$ by $22.4 \%$ of the estimated population, these sizes were a medium category of giant prawns. This was following Figure 2 where the distribution of giant prawns criteria based on the total length that explained the size distribution of giant prawns located in Sembakung waters. Based on the comprehensive data processing of giant prawns, there were three criteria of total length, they were small shrimp with a size $11.1 \pm$ $1.2 \mathrm{~cm}$ (31.4\%), the medium was $13.85 \pm 1.45$ (59.5\%), and large was $17.34 \pm 1.95 \mathrm{~cm}(9 \%)$. These explained that there was a degradation of giant prawns catch that refers to total length, so it causes the dominant size that was found were medium and small size. This was suitable with the exploitation rate of giant prawns in Figure 13 which explains the overfishing exploitation reaches $85 \%$ for male giant prawns and $78.6 \%$ for female giant prawns.
According to Mallawa (2005) that the dominance of small shrimp in the catch causes less recruitment and population growth so the population stock in getting disturbance that can interfere with sustainability in nature.

Based on the regression equation $M$. rosenbergii of male, the value of $b=2,644$ was obtained. According to Effendie (1997) explains that the growth of $b<3$ has negative allometric growth properties which means that the growth of total length was faster than total weight where the correlation between them was 0.8275 . According to Sarwono (2006), the correlation between 0.75-0.99 has a very strong correlation refers to negative allometric and it showed in Table 1. According to Sofian and Sari (2018), the growth of fresh male giant prawns in the Ogan River of South Sumatra has negative allometric. According to Murni (2004), explains the growth in terms of b value can affect factors in such as the ability to use feed and food availability. $M$. rosenbergii female was showed negative allometric due to the value of $b<3$ was 2.3484. According to Effendie (2002), stated the growth of giant prawns was negative allometric where the total length was faster than the total weight with a very strong correlation value. Sarwono (2006) in Table 1 explained that if the correlation value between 0.750.99 , it has a very strong correlation and refers to negative allometric. The growth of giant prawns was negative allometric because the area was salinity so it requires a lot of energy to adapt. This was consistent with Murni (2004) that external factors like water temperature, salinity, food availability, and the presence of predators could affect the growth. 
Based on research results obtained from all catches of fishermen as many as 14 times of sampling, showed that body shape of giant prawns according to Indarjo et al. (2020a), Indarjo et al. (2020b), Salim (2013), Salim (2015) found three criteria for male giant prawns, they were thin and fat body shape of male giant prawns had the same percentage of $48.89 \%$, the criteria for very fat was $2.22 \%$, while the ideal body shape and very thin were not found. In the condition index criteria according to (Indarjo et al. (2020a), Salim (2013), Salim (2015) obtained 4 criteria regarding the body shape of female giant prawns, i.e. thin body shape was $47.88 \%$, the ideal body shape was $3.03 \%$, the fat body shape was $46.67 \%$ and very fat body shape was $2.42 \%$. It explained that the condition of giant prawns in nature experienced a body shape degradation where almost half of the population has a thin body shape. It was suspected that giant prawns in Sembakung waters undergo a process of adaptation to the high salinity, one of them was the edge of the Sembakung waters that consisted of several rivers which had zero salinity (fresh) value, resulting in osmoregulation changes in the body of giant prawns (Salim and Anggoro, 2019).

The growth model of Von Bertalanffy can explain the growth of male and female giant prawns in the early growth male period at zero days has a total length of $2,463 \mathrm{~cm}$ and female of $2.261 \mathrm{~cm}$, and the maximum length male reaches $21.219 \mathrm{~cm}$ and female of 18.042 $\mathrm{cm}$. The male giant prawns in reaching a maximum length of $21.219 \mathrm{~cm}$ were estimated to have 89 days of age and the female giant prawn maximum length of $18.042 \mathrm{~cm}$ were estimated to have 68 days of age. Figure 12 explains that the growth of female giant prawns begins to occur constant growth when it lengths about $20 \mathrm{~cm}$ with 30 days of age. This explains that there is no total length growth for male and female giant prawns at the age but it towards to the body weight. This was following Lagler (1949) and Lagler (1969) expressed that if giant prawns had reached maximum growth then the growth would towards body maintenance.

\section{Conclusion}

The results obtained the habitat of $M$. rosenbergii with a salinity of $6.5 \pm 0.5 \mathrm{ppt}$; temperature of $28.5 \pm 0.5^{\mathrm{O}} \mathrm{C} ; \mathrm{pH} 6$ (Acidic). The sex ratio for males and females was 1: 3.67. Growth of the allometric male and female was negative allometric. The Index condition of male and female had a fat body and thin body. The Von Bertalanffy growth model of male and female was $21.219 \mathrm{~cm}$ and $18.042 \mathrm{~cm}$. Total mortality of male and female was 2.257 and 1.528 ; catch mortality was 1.92 and 1.201 ; natural mortality male and female was 0.3375 and 0.3269 ; exploitation rate was 0.85 and 0.786 .

\section{Acknowledgment}

Researchers would like to thank the Ministry of Research and Technology / National Innovation Research Agency, Director of Industrial Technology Development and Research and Service Institute (LPPM) of the University of Borneo Tarakan (UBT) for the National Innovation System Research Incentives (INSINAS) of Phase 2 of year 2020.

\section{Authors' Contributions}

Author's Contribution All authors have contributed to the final manuscript. The contribution of each author as follow, Hariyadi collected the data. All authors discussed the results and contributed to the final manuscript.

\section{Conflict of Interest}

The authors declare that they have no competing interests

\section{Funding Information}

This research was partially supported by Ministry of Research and Technology / National Innovation Research Agency, Director of Industrial Technology Development with grant number: 17/E1/KPT/2020 for the National Innovation System Research Incentives (INSINAS) of Phase 2 of year 2020.

\section{References}

Ali, F. (2009). Mendongkrak produksi udang galah. Jakarta: Niaga Swadaya.

Badan Pusat Statistik. (2013). Statistik Indonesia 2013. In Katalog BPS. Jakarta: Badan Pusat Statistik

Badan Pusat Statistik. (2014). Statistik Indonesia 2013. In Katalog BPS. Jakarta: Badan Pusat Statistik

Badan Pusat Statistik. (2016). Statistik sumber daya laut dan pesisir. Jakarta: Sub Direktorat Statistik Lingkungan Hidup.

Bal, D. V., \& Rao, K. V. (1984). Marine fisheries. New Delhi: Tata Mc. Graw Hill Publishing Company Limited. pp. 5-24

Batubara, \& Gustianty. (2016). Laju Pertumbuhan dan kelangsungan hidup udang galah (Macrobranchium rosenbergii de Man) skala laboratorium. Kisaran: Universitas Asahan.

Bertalanffy, V. L. (1938). A Quantitative theory of organic growth (Inquiries On growth Laws.II) $H$ man Biology, 10(2): 181-213.

Davassi, L. A. (2011). Survival and Growth of the Fresh water Prawn Macrobrachium rosenbergii in Relation to Different Nutrients Composition. Journal of Fisheries and Aquatic Science, 6: 64965 
De Man, J. G. (1879). On some species of the genus Palaemon Fabr. with descriptions of two new forms. Notes from the Leyden Museum, 1(3): 165184.

Effendie, M. I. (1979). Metoda biologi perikanan. Bogor: Yayasan Dewi Sri.

Effendie, M. I. (2002). Biologi perikanan. Yogyakarta: Yayasan Pustaka Nusatama.

Effendie, M. I. (1997). Biologi perikanan. Yogyakarta: Yayasan Pustaka Nusatama.

Firdaus, M., Salim, G., Cahyadi, J., Weliyadi, E., \& Bintoro, G. (2020). Model and nature of growth of red snapper fish Lutjanus argentimaculatus (Forsskål, 1775) fishing catch of bottom fish pots in Bunyu Waters, North Kalimantan. Aquaculture, Aquarium, Conservation \& Legislation Bioflux, 13(3): 1410-1421

Firdaus, M., \& Salim, G. (2018). Study Population of Mudskipper (Periophthalmus barbarus) in Bekantan and Mangrove Conservation Area, Tarakan City, North Kalimantan. Borneo Saintek of University of Borneo Tarakan Journal 1(3): 6878.

Firdaus, M., Lelono, T. D., Saleh, R., Bintoro, G., \& Salim, G. (2018). The expression of the body shape in fish species Harpadon nehereus (Hamilton, 1822) in the waters of Juata Laut, Tarakan City, North Kalimantan. Aquaculture, Aquarium, Conservation \& Legislation Bioflux, 11(3): 613-624.

Firdaus, M., \& Salim, G. (2011). Mengkaji populasi ikan puput (Ilisha elongata) yang berasal dari perairan Kota Tarakan. Harpodon, 4(1): 46-53.

Gulland, J. A., \& Holt, S. J. (1959). Estimation of growth parameters for data at unequal time intervals. ICES Journal of Marine Science, 25(1): 47-49.

Gunaratne, V. S., De Silva, D. W. L. U., Sandaruwan, K. P. G. L \& Thilakarathne, M. T. N. (2019). Insights of fresh water giant prawns (Macrobrachium rosenbergii) shery in North Central Province of Sri Lanka. National Aquatic Resources Research and Development Agency (NARA), Crow Island, Colombo 15, Sri Lanka Scientic Sessions.

Habashy, M. M., \& Hassan, M. M. S. (2011). Effects Of temperature and salinity on growth and reproduction of the freshwater prawn, Macrobrachium rosenbergii (CrustaceaDecapoda) in Egypt. International Journal of Environmental Science And Engineering, 1(1): 83-90.

Indarjo, A., Salim, G., Zein, M., Septian, D., \& Bija, S. (2020a). The population and mortality characteristics of mangrove crab (Scylla serrata) in the mangrove ecosystem of Tarakan City, Indonesia. Biodiversitas, 21(8): 3856-3866.
Indarjo, A., Salim, G., Zein, M., Soejarwo, P. A., Nugraeni, C. D., Bija, S., \& Pham, Y. T. H. (2020b). Characteristics of Von Bertalanffy growth, allometric, condition index and mortality of Periophthalmus barbarus in mangrove and Bekantan Conservation Area (KKMB), Tarakan, North Kalimantan. Indonesian Journal of Marine Sciences/Ilmu Kelautan, 25(1): 31-38.

Indarjo., Salim, G., Amir, F., Supriadi, S., Soejarwo, P. A., Nugraeni, C. D., Prakoso, L. Y., Ambariyanto, A., Firdaus, M., \& Ransangan, J. (2020c). Growth Characteristics Layur Fish Lepturacanthus savala in Juata Waters, Tarakan, Indonesia, Indonesian Journal of Marine Sciences, 25(2): 127-134

Ipandri, Y. (2017). Kelangsungan hidup dan perkembangan larva udang galah (Macrobrachium rosenbergii) asahan pada salinitas berbeda. Skripsi. Universitas Lampung

Kementerian PPN/ Bappenas, Direktorat Kelautan dan Perikanan. (2014). Kajian strategi pengelolaan perikanan berkelanjutan.

Khalis, M., Mallawa, A., \& Amir, F. (2016). Kajian kondisi stok udang galah (Macrobrachium rosenbergii) di Sungai Waelawi Kabupaten Luwu Utara Provinsi Sulawesi Selatan. Jurnal Ilmu Pengetahuan dan Teknologi Sains Pemanfaatan Sumberdaya Perikanan, 3(5): 411- 422.

Kurup, B. M., Sebastian, M. J., Sankaran, T. M., \& Rabindranath, P. (1992). Fishery and biology of Macrobrachium spp. of the Vembanad Lake. (pp. 78-89). In E. G. Silar (Ed.) Freshwater prawns. KAU. Lagler, K. F. (1949). Studies in freshwater fishery biology. The Progressive Fish Culturist, 11(3): 194.

Lagler, K. F. (1969). Manmade lakes: planning and development. FAO Rome.

Lidyana, V. (2019) Penjelasan lengkap KKP soal ekspor produk perikanan turun. detikfinance [online].

Mahendra, \& Rizal, M. (2019). The growth and efficiency of galah shrimp feed (Macrobrachium rosenbergii De Man) with the addition of caffeinein commercial feed. Budapest International Research in Exact Sciences Journal, 1(4): 112-120.

Mallawa, I. C. S. (2005). Aktivitas antibakteri senyawa bioaktif spons laut terhadap Staphylococcus aureus dan Vibrio cholera. Skripsi. Makassar: Fakultas Ilmu Kelautan dan Perikanan Universitas Hasanudin.

Murni, I. (2004). Kajian tingkat kematangan gonad udang galah (Macrobrachium rosenbergii de Man) di Muara Sungai Kapuas Pontianak Kalimantan Barat. Bogor; Sekolah Pascasarjana. Institut Pertanian Bogor. 
Muchlisin, Z. A., Nurfadillah, N., Arisa, I. I., Rahmah, A., Putra, D. F., Nazir, M., \& Zulham, A. (2017). Short communication: fish fauna of Lake Lauik Tawar and Lake Laulo, Simeulue Island, Indonesia. Biodiversitas, 18(2): 752-757.

Munasinghe, N. H. D., \& Thushari, N. G. G. (2010). Analysis of morphological variation of four populations of Macrobrachium rosenbergii (De Man,1879) (Crustacea: Decapoda) in Sri Lanka. Ceylon Journal of Science (Biological Sciences), 39: 53-60.

New, M. B. (2002). Farming freshwater prawns: a manual for the culture of the giant river prawn (Macrobrachium rosenbergii) (Issue 428). Food \& Agriculture Org. United Kingdom.

New, M. B., \& Kutty, M. N. (2010). Commercial freshwater prawn farming and enhancement around the world. In: New, M. B., W. C. Valenti, J.H. Tidwell, L. R. D’Abramo, and M. N. Kutty (Eds). Freshwater prawns biology and farming. Wiley Blackwell Publishing, pp: 18-34.

Nikijuluw, V. P. H. (2002). Fisheries resource management regime. Jakarta: Pustaka Cisendo.

Paul, P., Rahman, A., Hossain, M. M., Islam, S., Mondal, S., \& Haq, M. (2016). Effect of stocking density on the growth and production of freshwater prawn (Macrobrachium rosenbergii). International Journal of Fisheries and Aquaculture Sciences, 6 (1): 77-86.

Pauly, D. (1984). Fish population dynamics in tropical waters: a manual for use with programmable calculators. International Center for Living Aquatic Resources Management.

Putra., D. F., Trisyahdar, T. N., Dewiyanti, I., \& Muhammadar, A. A. (2018). Effect of enhanced Artemia with gamat emulsion on growth performance and survival rate of white shrimp Litopenaeus vannamei larvae. IOP Conference Series: Earth and Environmental Science, 216 (2018) 012005.

Raman, K. (1964). On the location of nursery ground of the giant prawn Macrobrachium rosenbergii (de Man). Current of Science, 33(1): 27-28

Raman, K. (1967). Observation on the fishery of giant freshwater prawn Macrobrachium rosenbergii (deMan). Proceedings of the Symposium on Crustacea. Part II. Proceedings of the Symposium on Crustacea. Biology Association. India BS33B, 253-279 p.

Raswin, M. M., Hitam, M. S., \& Aziz, K. A. (1981, September). Study on some biological aspects of Macrobrachium sintangense (de Man) [Indonesian]. Seminar hasil - hasil Penelitian dan Pengembangan Energi Pedesaan Daerah Lingkar Kampus IPB (Institut Pertanian Bogor). Bogor (Indonesia). 113 p.
Salim, G. (2013). Nilai indeks kondisi dari ikan Siganus javus berdasarkan hasil tangkapan nelayan di perairan Juata Kota Tarakan. Jurnal Harpodon Borneo, 8(1): 37-42.

Salim, G. (2015). Analisis pertumbuhan allometri dan indeks kondisi caesio cunning didapatkan dari hasil tangkapan nelayan Kota Tarakan. Jurnal Harpodon Borneo, 8(1): 35-42.

Salim, G., \& Anggoro, S. (2019). Domestikasi udang: prospek masa depan sumber pangan dari laut. Deepublish.

Sarwono, J. (2006). Metode penelitian kuantitatif dan kualitatif. Yogyakarta: Graha Ilmu.

Sofian, S., \& Sari, Y. P. (2018). Kajian terhadap pola pertumbuhan udang galah (Macrobrachium rosenbergii) di Sungai Ogan Sumatera Selatan. Jurnal Fishtech, 7(2): 120-123.

Sparre, P., \& Venema, S. C. (1999a). Introduksi pengkajian stok ikan tropis: Buku 2, latihan. Jakarta: Pusat Penelitian dan Pengembangan Perikanan.

Sparre, P., \& Venema, S. C. (1999b). Introduksi pengkajian stok ikan tropis. Buku I, manual. Kerjasama Organisasi Pangan dan Perserikatan Bangsa-Bangsa dengan Pusat Penelitian dan Pengembangan Perikanan. Jakarta: Badan Penelititan dan Pengembangan Pertanian.

Sparre, P., \& Venema, S. C. (1998). Introduction to tropical fish stock assessment, Vol. 1. FAO Fisheries Technical Paper, Rome. Part 1: Manual. FAO Documento Técnico de Pesca. No. 306.1 Rev. 2.

Sparre, P., \& Venema, S. C. (1998). Introduction to tropical fish stock assessment. Part 1: Manual. FAO Documento Técnico de Pesca. No. 306.1 Rev. 2 (p. 434).

Steel, R. G. D., \& Torrie, J. H. (1993). Prinsip dan prosedur statistika (Terjemahan by B. Sumantri). Jakarta: PT. Gramedia.

Waluyo, A., Mulyana, M., \& Ali, F. (2019). Tingkat kelangsungan hidup dan pertumbuhan udang galah (Macrobrachium Rosenbergii De Man) pada media bersalinitas. Jurnal Mina Sains, 4(2): 107126.

Weatherley, A. H. (1972). Growth and ecology of fish population. London: Academic Press.

Widowati, H. (2019). Indonesia eksportir udang beku terbesar keempat di dunia. Databoks [online] 